\title{
Knowledge Management Practices in Oman Construction Sector
}

\author{
Abdulaziz Almarshoudi, Subashini Suresh, and Suresh Renukappa
}

\begin{abstract}
Implementing the strategies of Knowledge Management (KM) in the construction industry in Oman can produce significant benefits, such as continuous improvement and the improved performance of construction projects. In addition, the need to understand the determinants of successful Knowledge Management cannot be underestimated in organisations in the Middle East; specifically, those which are members of the Gulf Cooperation Council (GCC). The accelerated development in recent years regarding the GCC countries, highlights the need for these nations and their organisations to empower themselves through Knowledge Management. Nevertheless, very little empirical research has been conducted to understand this phenomenon. This paper investigates the role of Knowledge Management in relation to reducing the Cost of Poor Quality in the construction industry in Oman. Data was collected via questionnaires and interviews with Omani construction engineers from public and private sector. The findings reveal that knowledge capture and knowledge sharing are paramount to the contributory factors to the Cost of Poor Quality in practice, which includes the cost of errors and omissions, cost of design changes and the cost of poor skills.
\end{abstract}

Index Terms-Knowledge management, cost of poor quality, Oman, construction sector.

\section{INTRODUCTION}

Knowledge Management refers to obtaining information, capturing, managing and sharing it by involving people, cultures, processes and technologies [1]. According to Frost [2], Knowledge Management is the systematic management of an organization's knowledge assets for creating value and meeting tactical and strategic requirements. This method consists of the initiatives, processes, strategies and systems that sustain and enhance the storage, assessment, sharing, refinement, and creation of knowledge. The construction industry in Oman is a significant indicator of the development as it creates opportunities for investment across several related sectors. The construction industry plays an essential part in the growth of a country's economy and is vital in the development plans of nations [3]. Knowledge Management (KM) has become necessary in the construction industry to reduce the Cost of Poor Quality (COPQ). There are several contributory factors related to the causes of poor quality, such as poor skills, insufficient knowledge of processes and

Manuscript received February 12, 2018; revised May 20, 2018.

Abdulaziz Almarshoudi is with University of Wolverhampton, WV1 1LY, UK (e-mail: A.Almarshoudi@wlv.ac.uk).

Subashini Suresh and Suresh Renukappa are with Faculty of Science and Engineering, University of Wolverhampton, Wolverhampton, WV1 1LY, UK (e-mail: s.subashini@wlv.ac.uk, suresh.renukappa@wlv.ac.uk). procedures, and poor planning and scheduling. Organisational success depends largely on managing knowledge [4]. Consequently, it has become a vital part of organisational strategy. It is therefore important to examine the aspects relating to Knowledge Management and Organisational Strategy. In addition, organisations classify KM initiatives as part of their long-term strategy so that their organizational knowledge can be retained [5]. However, the novelty of Knowledge Management was recently-introduced in the Middle East, transferred by professionals and experts from the West. This delay in the emergence of Knowledge Management was due to the era of political unrest, social conflicts and economic bottlenecks occurring in Middle Eastern countries since the 1990s [6].

From the existing literature, several barriers have been identified for KM, for instance the lack of commitment by senior management. Senior management is extremely influential in the expansion of organisational structure, technological infrastructure and various decision-making processes [4]. These started with the Gulf War (Historical Events on 30th November), and did not end until the Arab Spring uprisings in the latter part of 2010 [8]. The economic development of Middle East states remains troubled with inadequate income distribution, poverty, high unemployment, and inadequate investments [6]. The region has been divided into sub-regional groups with a notable gap in terms of income, public expenditure, and purchasing power [8]. Owing to all these dilemmas and tensions surrounding the region, awareness on the essence of Knowledge Management has been completely disregarded [6].

There are many intangible benefits to Knowledge Management, according to Clark and Soliman [5]. They state that Knowledge Management assists with the improvement of performance in manufacturing, in terms of quality, time, speed and reliability, besides reducing production costs [9].There are certain benefits related to Knowledge Management in the business sector that can generate sustainable competitive advantage [10]. The key benefits of Knowledge Management in the construction industry include innovation, performance improvement, improved construction project deliveries, facilitating knowledge transfer via various projects, in addition to a quick response to clients' needs and other external factors, and for instance engaged tacit knowledge and increase in value [11]. This study will investigate the importance of Knowledge Management in the construction industry in Oman. Furthermore, this paper determines the reasons and significance of KM to reduce COPQ in the construction industry in Oman. 


\section{RESEARCH Methodology}

The method which is used to collect data and information concerning the purpose of making business decisions is termed 'research methodology'. It may include previous research, a questionnaire, interviews and other research methods, and it could comprise both present and historical information [12]. This study has adopted mixed methodology; primary sources termed qualitative sources from the interviews and quantitative sources from the questionnaires, in addition to secondary sources via the literature review [12].

The questionnaire was administered through several public and private construction sectors in Oman from 2nd November to 14th November, 2017. Thereafter interviews were conducted; each interview took between 45-60 minutes. The researcher used Microsoft Excel to analyse the findings obtained from the questionnaires and interviews. Descriptive statistics was used for analyzing data obtained from questionnaires and thematic analysis was used for interview data.

Table I shows the involvement of participants from the public and private sector regarding the interviews and questionnaires.

TABLE I: PARTICIPANT'S DETAILS

\begin{tabular}{llll}
\hline \multicolumn{4}{c}{ TABLE I: PARTICIPANT'S DETAILS } \\
& Private & Public & Total \\
& sector & sector & \\
\hline Questionnaires & 10 & 30 & 40 \\
Interviews & 2 & 3 & 5 \\
\hline \hline
\end{tabular}

A total of five interviews were conducted of which three are from public sector and two from private sector from construction sector in Oman. Moreover, research data was collected via the questionnaire from three public construction companies and one private construction company in Oman.

\section{FINDINGS}

The paper presents and discusses the findings on the optimisation of Knowledge Management to reduce the Cost of Poor Quality on construction projects. It discusses the findings on the contributory factors to the Causes of Poor Quality in practice, which includes the cost of errors and omissions, cost of design changes and the cost of poor skills. Prior to that Tables II, IIIand IV below reveals the qualitative and quantitative findings.

Table II illustrates the benefits and barriers pertaining to Quality Management in the public and private construction sectors in Oman. The quantitative sources identified several benefits of Quality management. These comprise, improved work outcomes, increased client satisfaction, save costs and deliver on time. Furthermore, it shows several barriers for example, in the public sector, the principal barriers to applying Quality Management are unskilled staff, poor project management execution and lack of regular assessment Additionally, the challenges to employing Quality Management in the private sectors are numerous, such as, non-educated employees, insufficient time for discussing Knowledge Management during the project process and budget constraints. In the quantitative sources (questionnaire), the researcher has ranked in descending order, from the highest to the lowest percentage (72\%) regarding Knowledge Management in the construction industry in Oman.

TABLE II: BENEFITS AND BARRIERS OF QM

\begin{tabular}{|c|c|c|c|}
\hline \multicolumn{4}{|c|}{ Interviews } \\
\hline Private sector & & Public sector & \\
\hline Benefits & Barriers & Benefits & Barriers \\
\hline $\begin{array}{l}\text { Improve work } \\
\text { outcomes. }\end{array}$ & $\begin{array}{l}\text { Lack of } \\
\text { management } \\
\text { commitment. }\end{array}$ & $\begin{array}{l}\text { Financial } \\
\text { benefits. }\end{array}$ & $\begin{array}{l}\text { Lack of } \\
\text { communication. }\end{array}$ \\
\hline $\begin{array}{l}\text { Increase client } \\
\text { satisfaction. }\end{array}$ & $\begin{array}{l}\text { Limitations of the } \\
\text { labour. }\end{array}$ & $\begin{array}{l}\text { Increase } \\
\text { experience. } \\
\text { Complete }\end{array}$ & $\begin{array}{l}\text { Lack of } \\
\text { awareness of } \\
\text { QM. }\end{array}$ \\
\hline $\begin{array}{l}\text { Cost } \\
\text { reduction. }\end{array}$ & $\begin{array}{l}\text { Staff are not able } \\
\text { to change the }\end{array}$ & $\begin{array}{l}\text { on time. } \\
\text { Improve }\end{array}$ & $\begin{array}{l}\text { Existing lack of } \\
\text { suitable }\end{array}$ \\
\hline $\begin{array}{l}\text { Defect } \\
\text { reduction. }\end{array}$ & $\begin{array}{l}\text { organisational } \\
\text { mentality. }\end{array}$ & $\begin{array}{l}\text { labour } \\
\text { skills. }\end{array}$ & training. \\
\hline $\begin{array}{l}\text { Delivery on } \\
\text { time. }\end{array}$ & $\begin{array}{l}\text { Lack of } \\
\text { improvement of }\end{array}$ & & $\begin{array}{l}\text { Insufficient } \\
\text { resources. }\end{array}$ \\
\hline Save costs. & $\begin{array}{l}\text { the quality of } \\
\text { measurement. }\end{array}$ & & \\
\hline \multicolumn{4}{|c|}{ Questionnaire } \\
\hline \multicolumn{4}{|c|}{ Benefits } \\
\hline \multicolumn{4}{|c|}{$\begin{array}{l}\text { (1) Improve product quality (40) } 100 \% \text {. } \\
\text { (2) Increase customer satisfaction (36) } 90 \% \text {. } \\
\text { (3) Increased competitive advantage (33) } 83 \% \text {. } \\
\text { (4) Increased staff motivation (33) } 83 \% \text {. } \\
\text { (5) Increase profitability (32) } 80 \% \text {. } \\
\text { (6) Improved cost efficiency (31) } 78 \% \text {. } \\
\text { (7) Improved reputation (29) } 74 \% \text {. }\end{array}$} \\
\hline
\end{tabular}

Contributory factors to the Cost of Poor Quality in the public and private sectors in Oman are identified in Table III. In the public sector, there are several factors pertaining to the Cost of Poor Quality, for instance, the lack of continuous follow-up by the consultant, low qualified staff with poor knowledge and inadequate knowledge of process procedures. Additionally, the factors related to the cost of poor quality the in the private sectors are multiple and comprise poor managerial auditing, poor financial auditing and lack of risk management skills. From the questionnaire, illustrate lack of incentives to motivate project staff is the highest contributory factor to the Causes of Poor Quality. The lowest contributory factors regarding the Causes of Poor Quality is the time constrained nature of projects.

Benefits and barriers of Knowledge Management public sectors and private sectors in Oman are identified in Table IV. The benefits for applying Knowledge Management are summarised from qualitative sources (interviews). For example, in the public sector, the main benefits are to meet client's expectations, reduce mistakes and avoiding completion delay. While the barriers noted are lack of assessment, unskilled staff and lack of awareness and knowledge of project management. However, the benefits of $\mathrm{KM}$ in the public sector in Oman are avoiding completion delay, reducing mistakes, meet client's expectations and handed over on time. In the private sector, the interviews reveal that the benefits concerning $\mathrm{KM}$ are reducing errors and omissions, gaining experience and avoiding losses on the project. The barriers to applying KM in the private sector are budget constraints, lack of educated employees and insufficient time for discussing $\mathrm{KM}$ during the project 
process.

TABLE III: CONTRIBUTORY FACTORS TO THE COST OF POOR QUALITY

\begin{tabular}{ll}
\hline \hline \multicolumn{2}{c}{ Interviews } \\
\hline \hline Private sector & Public sector \\
\hline Poor financial auditing. & Lack of continuous follow-up \\
Poor managerial auditing. & by the consultant. \\
Poor technical auditing. & Lack of skilled labour. \\
Lack of process standardisation. & Working with new concepts. \\
Lack of document control tools. & Working with unfamiliar \\
Poor communication plan. & designs on construction \\
Public demand and changing & processes. \\
specification by utility agencies. & No external auditing. \\
Poor structural auditing prior to & Lack of learning from past \\
project implementation process. & experiences. \\
Poor architectural auditing before & The emergence and evolution of \\
implementation process of the & materials and designs. \\
project. & Inadequate knowledge of \\
Lack of risk management. & process procedures. \\
Various government laws that & Poor planning and scheduling. \\
prevent the recruitment of some & Poor communication plan. \\
skilled nationalities. & Poorly qualified staff with \\
& inadequate knowledge. \\
& Poor communication \\
\hline
\end{tabular}

(1) Lack of incentives to motivate project staff (38) $95 \%$.

(2) Lack of understanding of KM concepts by project staff (36) $90 \%$.

(3) Lack of collaborative working by project organisations to create new knowledge (33) $83 \%$.

(4) Lack of knowledgeable managers on projects (34) $80 \%$. (5) Time constrained nature of projects (24) $60 \%$.

Nevertheless, the findings from the questionnaire show that there are several benefits for applying KM in the construction industry in Oman. Table IV illustrates that the highest significant benefit is the sharing of knowledge among project team members, whereas the lowest benefit is engaging experts to facilitate knowledge management on projects.

TABLE IV: BENEFITS AND BARRIERS OF KM

\begin{tabular}{|c|c|c|c|}
\hline \multicolumn{4}{|c|}{ Interviews } \\
\hline \multicolumn{2}{|c|}{ Private sector } & \multicolumn{2}{|l|}{ Public sector } \\
\hline Benefits & Barriers & Benefits & Barriers \\
\hline $\begin{array}{l}\text { Gaining } \\
\text { experience } \\
\text { and } \\
\text { learning } \\
\text { material. } \\
\text { Manage } \\
\text { and direct } \\
\text { project } \\
\text { procedures. } \\
\text { Avoid } \\
\text { losses in the } \\
\text { project. } \\
\text { Reduce } \\
\text { errors and } \\
\text { omissions. }\end{array}$ & $\begin{array}{l}\text { Differences in } \\
\text { mentalities and } \\
\text { cultures in some } \\
\text { countries hindering } \\
\text { multinational } \\
\text { companies from } \\
\text { applying it correctly. } \\
\text { Budget constraints. } \\
\text { Employees } \\
\text { insufficiently } \\
\text { educated in the field } \\
\text { of specialisation. } \\
\text { Insufficient time to } \\
\text { discuss Knowledge } \\
\text { Management during } \\
\text { the project process. }\end{array}$ & $\begin{array}{l}\text { Reducing } \\
\text { mistakes. } \\
\text { Handed } \\
\text { over on } \\
\text { time. } \\
\text { Meet } \\
\text { client's } \\
\text { expectation } \\
\text { s. } \\
\text { Avoid delay } \\
\text { of } \\
\text { completion. }\end{array}$ & $\begin{array}{l}\text { Lack of } \\
\text { awareness and } \\
\text { knowledge of } \\
\text { project } \\
\text { management. } \\
\text { Lack of } \\
\text { assessment. } \\
\text { Lack of } \\
\text { leadership. } \\
\text { Time } \\
\text { constraints. } \\
\text { Procurement } \\
\text { strategy. } \\
\text { Unskilled staff. } \\
\text { Poor project } \\
\text { management } \\
\text { execution. }\end{array}$ \\
\hline \multicolumn{4}{|c|}{ Questionnaire } \\
\hline \multicolumn{4}{|c|}{ Benefits } \\
\hline \multicolumn{4}{|c|}{$\begin{array}{l}\text { (1) Sharing of knowledge among project team members (35) } 83 \% \text {. } \\
\text { (2) Capturing lessons learnt at various stages of the project (34) } 80 \% \text {. } \\
\text { (3) Capturing knowledge from other projects for use on current project } \\
\text { (34) } 80 \% \text {. } \\
\text { (4) Using mentoring programmes to facilitate knowledge transfer among } \\
\text { staff (29) } 78 \% \text {. } \\
\text { (5) Engaging experts to facilitate Knowledge Management on projects } \\
\text { (26) } 72 \% \text {. }\end{array}$} \\
\hline
\end{tabular}

\section{KM AND COPQ FINDINGS}

According to [13], design checks and verifications are beneficial to identify mistakes. If lessons are not learned from previous projects and appropriate training, and skill development implementation is not provided, their usefulness is restricted. There is therefore a Knowledge Management aspect to Quality Management in reducing quality related costs. Although [14], made the point that in projects where poor quality management is implemented non-conformance costs may be significantly higher, [11] established that the costs of design-related change orders affect contract value [15]. Also, identified client change as one of the predictors of the cost of rework.

The questionnaire had asked the benefits of optimising Knowledge Management for reducing the causes of poor quality. The percentages of total respondents ranked between $80-100 \%$ agree about all the benefits. For example, the percentage for improving the quality of product was $100 \%$, the percentage for increasing customer satisfaction was $90 \%$ and the percentage for increasing staff motivation was $85 \%$. Moreover, the percentage related to improving cost efficiency and profitability was $80 \%$. The analyses show that $85 \%$ of the respondents agree that Knowledge Management contributes to increasing the reputation and the competitive advantage of construction organisations. From the discussion above, the significant role of Knowledge Management in reducing the cost of poor quality with regards to increasing customer satisfaction, the quality of product and the reputation of construction organisations is evident.

In questionnaire, respondents were asked to rate the level of impact of Knowledge Management processes on the constituent elements of causes of poor i.e. design changes, errors and omissions, and poor skills, based on their own experiences on construction projects. The data analysis indicates positive impact of capturing lessons learnt at various stages of the project, in relation to reducing the cost of design changes on the capturing lessons learnt at various stages of the project is $85 \%$. Furthermore, the positive percentage for capturing lessons learnt at various stages of the project on the impact of reducing the cost of construction errors is $83 \%$. Additionally, the impact of capturing lessons learnt at various stages of the project for reducing the cost of poor skills is $73 \%$. These results indicate that the capturing lessons learnt at various stages of the project have a significant positive impact on reducing the cost of design change, construction errors and poor skills.

In questionnaire, respondents were asked to identify the impact of capturing knowledge from other projects for use on current projects with the aim of reducing the cost of design changes, construction errors and poor skills. It is evident from the results of the questionnaire that the positive percentage of capturing knowledge from other projects for use on current projects to reduce the cost of design changes is $85 \%$. Moreover, the positive percentage of capturing knowledge from other projects for use on current projects to reduce the cost of construction errors is $75 \%$. In addition, this table identifies the positive percentage of capturing knowledge from other projects for use on current projects to reduce the cost of poor skills is $80 \%$. Consequently, capturing 
knowledge from other projects for use on current projects to reduce the causes of design changes is important to reduce the causes of design changes, construction errors and poor skills in the construction industry.

The next question was designed to identify the impact of sharing knowledge among project team members on reducing the cost of design changes, construction errors and poor skills. The results obtained from the questionnaire illustrate a positive percentage of sharing knowledge among project team members to reduce the causes of design changes is $85 \%$. Furthermore, the positive percentage of sharing knowledge among project team members to reduce the cases of construction errors is $75 \%$. The positive percentage related to sharing of knowledge among project team members in reducing the causes of poor skills is $80 \%$. Therefore, it is apparent from discussion above that the sharing of knowledge among project team members is crucial regarding reducing the cases of design change, construction errors and poor skills.

The analysis of the next question indicates a positive percentage related to using mentoring programmes to facilitate knowledge transfer among staff on reducing the causrs of design change is $74 \%$. In addition, the positive percentage pertaining to using mentoring programmes to facilitate knowledge transfer among staff on reducing the causes of construction errors is $83 \%$. The positive percentage related to using mentoring programmes to facilitate knowledge transfer among staff on reducing the causes of design change is $68 \%$. It is obvious from the discussion above, that using mentoring programmes to facilitate knowledge transfer among staff can have an impact on reducing the causes of design change, construction error and poor skills in construction projects.

Furthermore, question was asked to identify the impact of engaging experts to facilitate Knowledge Management on projects with the aim of reducing the causes of design changes, construction errors and poor skills. The results of the questionnaire illustrate the impact of engaging experts to facilitate Knowledge Management on projects to reduce the cases of design change, shows a positive percentage, which is $73 \%$. Furthermore, the positive percentage for the impact of engaging experts to facilitate Knowledge Management on projects to reduce the cases of construction errors is $73 \%$. The positive percentage for engaging experts to facilitate Knowledge Management on projects to reduce the cases of poor skills is $70 \%$. Therefore, engaging experts to facilitate Knowledge Management on projects is exceedingly important for reducing the cases of the design change, construction errors and poor skills during construction work.

The effectiveness of KM tools in reducing design changes and reduce poor skills. It was revealed that for design change the five highest ranking tools are: Knowledge Sharing Workshops, Peer Assistance, Blogs, Facebook and Email. This is an interesting set of results as they are all interlinked. They all relate to project team capturing, sharing and retaining valuable lessons learnt from on-going or concluded projects. Not surprisingly, these tools have revealed a high level of effectiveness in reducing design changes and associated costs on projects, according to the results.

The five KM tools in reducing poor skills revealed are:
Post-Project Reviews, Competency Management, Peer Assistance, Lessons Learnt Management Systems and Knowledge Sharing Workshops.

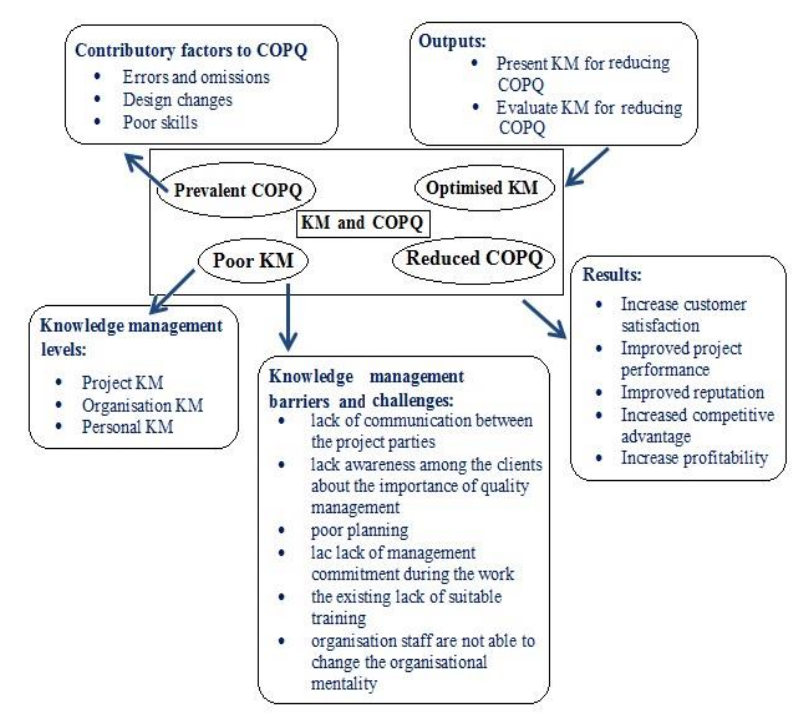

Fig. 1. Framework for reduction of COPQ through KM.

\section{Conclusions}

In today's fast-paced economy, an organisation's knowledge base is quickly becoming its only sustainable competitiveness. As such, this resource must be captured, protected, cultivated and shared amongst organisational members. Increasingly, however, competitiveness is to be gained by making individual knowledge available within organisation and transforming it into organisational knowledge. Organisational knowledge complements individual's knowledge, making it stronger and broader. The full utilisation of an organisation's knowledge base, coupled with the potential of individual's skills, competencies, thoughts, innovations, and ideas, will enable an organisation to compete more effectively in the future. In this paper, knowledge management practices are explored and reported in the context of the contributory factory (causes of design change, construction errors and poor skills) for COPQ in Oman construction sector and framework for reduction of COPQ through KM is presented (see Fig. 1). It concludes that capturing lessons learnt at various stages of the project, capturing knowledge from other projects for use on current projects and sharing of knowledge among project team members is crucial regarding reducing the cost of design change, construction errors and poor skills.

It also revealed mentoring programmes to facilitate knowledge transfer among staff can have appositive impact on reducing the cost of design change, construction error and poor skills in construction projects. The emphasis is on the capture and share of tacit knowledge. There is an urgent need for improved awareness and understanding of the challenges and significance of knowledge. Some form of guidance (roadmap/framework) is perceived as a way forward to facilitate improved competitiveness in Oman construction industry through effective knowledge management initiatives. 


\section{REFERENCES}

[1] Z. Wahl, Knowledge management in 2017, KMInstitute. [online] Kminstitute.org. http://www.kminstitute.org/blog/knowledge-management-2017.

[2] A. Frost, Knowledge management definition. [online]. Knowledge-management- tools.net. Available: http://www.knowledge-management-tools.net/knowledge-managemen t-definition.html

[3] R. Lakshmi, SSRG - Seventh sense research group, International Journal of Engineering, Science, Technology, Humanities and Social Science. [online]. Internationaljournalssrg.org. Available: http://www.internationaljournalssrg.org

[4] R. Olayinka, S. Suresh, and E. Chinyio, "The impact of knowledge management in reducing the cost of poor quality - The case of UK construction industry," in Proc. of the Institution of Civil Engineers Management, Procurement and Law, vol. 168, no. 4, pp. 177-188.

[5] A. A. ALSarhani, Knowledge Management in the public and private sectors organisations - The Road to Achieve Sustainable Competitive Advantage, Al-Rushd Library, Riyadh, Saudi Arabia.

[6] Y. K. Ammar, "Knowledge management practices in the middle east: Challenges and trends," International Journal of Innovation and Knowledge Management in Middle East and North Africa, vol. 5, no. 2, pp. 71-79, 2016.

[7] M. Ruthven, How to understand ISIS. [Online]. Available: http://www.nybooks.com/ articles/2016/06/23/how-to-understand-isis/

[8] A. Al-Roubaie and A. Al-Ameen, "Trade and knowledge creation in GCC Countries: The case for sustainable development," International Journal of Innovation and Knowledge Management in the Middle East and North Africa, vol. 4, no. 1, pp. 1-13.

[9] C. Armstead, "KM and process performance," Journal of Knowledge Management, vol. 3, no. 2, pp. 143-154, 1999.

[10] F. Soliman and K. Spooner, "Strategies for implementing knowledge management. role of human resources management," Journal of Knowledge Management, vol. 4, no. 4, pp. 337-345, 2000.

[11] M. L. Todorović, D. Č. Petrović, M. Mihić, V. L. Obradovićand, and S. D. Bushuyev, "Project success analysis framework: A knowledge-based approach in project management," International Journal of Project Management, vol. 33, no. 4, pp. 772-783, 2015.

[12] J. W. Creswell, Research Design Qualitative, Quantitative, and Mixed Methods Approaches, Thousand Oaks, CA: SAGE Publications.

[13] P. D. Love, D. J. Edwards, H. Watson, and P. Davis, "Rework in civil infrastructure projects: Determination of cost predictors," Journal of Construction Engineering \& Management. vol. 136, no. 3, pp. 275-282, 2010.

[14] J. Clark and F. Soliman, "A graphical method for assessing knowledge-based investments," Journal of Logistics and information Management, vol. 12, no. 1, pp. 63-77, 1999.

[15] C. O'Dell and C. J. Grayson, "If only we knew what we know: Identification and transfer of internal best practices," California Management Review, vol. 40, no. 3, pp. 154-174, 1998.

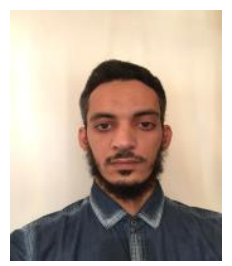

Abdulaziz Almarshoudi obtained civil engineering degree from the Higher College of Technology in Oman in 2010. He obtained master degree in the construction project management from University of Wolverhampton UK in 2018. He is working in the ministry of municipalities in Oman as a civil engineer from 2011 to date.

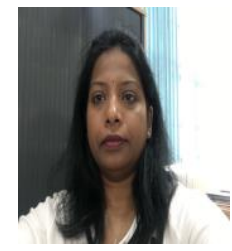

Subashini Suresh has over 19 years of experience in research, teaching and practice in the area of project management and has worked in the area of Architecture, Engineering and Construction (AEC) sector in UK, USA, UAE, Nigeria, Ghana, Italy, Netherlands and India. Currently, she is a reader of construction project management at the School of Architecture and Built Environment, University of Wolverhampton. She holds a Ph.D in knowledge management. She received rewarding excellence award for innovation in teaching and also for blended learning tutor. She has published over 150 academic publications, which include 27 journal papers, 95 conference papers, four articles, eight book chapters, 15 reports and three books. Her key areas of interest are as follows: construction project management, knowledge management, building information modelling, health and safety, sustainability/green construction, emerging technologies, quality management, leadership in change management initiatives, organisational competitiveness, business process improvement, lean construction, risk management, and Six Sigma leadership.

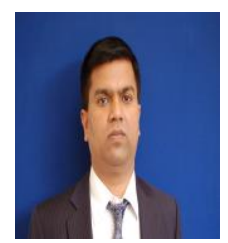

Suresh Renukappa currently serves as a senior lecturer in the Faculty of Science and Engineering at the University of Wolverhampton. He holds a Ph.D in managing change and knowledge associated with sustainability initiatives for improved competitiveness. He has over 20 years of research, consultancy, project management and teaching experience in a wide range of business and management areas across industrial sectors in both developed and emerging economies. His research interests cover, but not limited to, sustainability strategies for competitive advantage; carbon reduction strategies; corporate social responsibility; smart cities development; leading change towards sustainability; knowledge management; public private partnerships; cloud computing; infrastructure asset management; and sustainable infrastructure investment and development. He has successfully executed more than 30 large projects and authored over 120 papers which have been published in journals, book chapters and conference proceedings. 